\title{
Developing indicators for managing tourism in the face
}

\section{of peak oil}

Quote as:

Becken, S. (2008). Indicators for managing tourism in the face of peak oil. Tourism Management, 29, 695-705.

\begin{abstract}
In its present form, tourism is dependent on the availability of oil and is comparatively oil-intensive. While forecasts for future tourism growth are optimistic, there is also increasing evidence about the imminence of a peak in oil production and the economic effects that this would cause. Globally and on a destination level it will be necessary to consider how a transition towards fossil-fuel free economies might look like for tourism.It is therefore timely and prudent for the tourism sector to consider its current oil requirements and derive indicators for monitoring its oil consumption. In particular, destinations need indicators of the amount of oil consumed by the various markets from which they receive visitors. New Zealand is used as an example for assessing the oilintensity of its Top 10 countries of origin based on the 10 indicators. Overall, the least exposed markets for New Zealand with respect to oil are Australia, China, Singapore, and Taiwan, although a more detailed analysis would be required for markets that display very heterogeneous travel behaviour. Among the indicators, eco-efficiency is particularly important as it allows comparison of resource inputs with economic outputs.
\end{abstract}


Keywords: Tourist transport, peak oil, fuel, energy use, indicators, eco-efficiency 


\section{Introduction}

In its present form, tourism is dependent on the availability of oil. Earlier studies demonstrated that as a result of its inherent transport component, tourism is fuel driven and comparatively energy-intensive (Patterson \& McDonald, 2004; Gössling et al., 2005). While there are technological alternatives to fossil fuel based transport, there are also a wide range of limitations associated with each alternative. For air travel in particular, alternative fuel sources such as hydrogen are unlikely to be introduced in the near future (Peeters et al., 2006). Growth forecasts for tourism are optimistic: the United Nations World Tourism Organisations estimated growth in the order of $3.8 \%$ for interregional and 5.4\% for long-haul travel between 1995 and 2020 (UNWTO, 2001). On today's activity this would mean that in 2020 , there will be about 1.6 billion people engaged in international travel. Current tourism forecasts do not seem to take the challenge of oil availability into account and seem overly optimistic as a result. UNWTO (2006) has analysed the implications of oil price fluctuations for tourism, in particular in relation to aviation, however, this analysis focused on past events (e.g. oil shocks in the 1970s) and short term shocks since 2002 and did not consider the possibility of oil becoming increasingly scarce and unavailable.

The issues of energy consumption and associated long term futures of tourism have largely been omitted in tourism research to date. Only very recently, a study applied scenario analysis to investigate the implications of reduced oil availability for tourism in Scotland and to assist strategies for risk reduction (Yeoman et al., in press). The awareness of energy security and peak production of oil has traditionally been low in the tourism industry. More recently, concern about both energy consumption and 
climate change has increased dramatically; however, detailed responses and planning are still embryonic, although some operators such as Inter-City in New Zealand are now setting targets for being carbon-neutral within varying time frames.

\section{Peak oil}

While demand for oil is growing continuously, there is increasing concern about the imminence of an oil peak (i.e. a maximum of oil production) and the economic effects that a global decline in oil supply would cause. Global consumption of oil products in 2004 amounted to about 30 billion barrels, and demand is expected to grow by an average 1.6\% between now and 2030 (International Energy Agency (IEA), 2006). In the past, new reserves were discovered at a greater rate than consumption; however, now new field discoveries are declining and average only 10 billion barrels, well short of annual oil consumption (Hirsch, 2005). When oil is consumed faster than it can be replaced it will at some point be depleted. The reporting of oil reserves is not transparent and highly influenced by political agendas, both by governments and oil companies (for a detailed review, see Bentley, 2002). As a result, there is considerable discrepancy in estimates of the world's oil reserves, most often ranging between a total of 2000 to 3000 billion barrels (e.g. Duncan \& Youngquist, 1999, US Geological Survey, 2000, IEA, 2005).

Several models seek to provide trend lines for oil production over the next century (e.g. Campbell \& Laherrère, 1998; Hutter, 2006; World Energy Council, 2003). All the models suggest that there will be a decline in oil production at the very latest from 2040 , although the timing of the oil peak varies for the different models (typically between 5 and 10 years from now on, Bentley, 2002). Greene et al. emphasised the imminence by 
concluding "peaking of conventional oil production is almost certain to occur soon enough to deserve immediate and serious attention" (2006: 529), and Hirsch (2005) noted that "the date [of peaking] is almost irrelevant as mitigation will take much longer than a decade to become effective, because of the enormous scale of world consumption" (p.1).

Initially a peak in oil production would manifest itself as rapidly escalating prices followed by a worldwide oil shortage. The oil shocks of 1973 and 1979 illustrated how reduced availability of oil caused sharp rises in price, which resulted in declines in world Gross Domestic Product growth rate. Oil prices have reached US\$ 72 per barrel in April 2006; at the time of writing the price had fallen to below US\$ 60 per barrel. Up until now, fluctuations of oil prices have largely been a result of political events rather than declining reservoirs (Figure 1).

\section{FIGURE 1 ABOUT HERE}

Energy security, both short term and longer term, is a key concern in global oil production and supply (Dorian et al., 2006). At any one time there are about 54 days of stock in the OECD system plus 37 days in emergency stockpiles. Scenario analysis by Greene et al. (2006) showed that even under a wide range of demand and resource availability scenarios, the Middle East will continue to dominate oil production for the next decades, posing some concerns for energy security in relation to potential political crises. In the past, energy security was mainly seen from the perspective of political risks; however it is now recognised that there is also a physical risk as a result of peaking (Bentley, 2002). Given that most of the easily accessible oil reservoirs ("conventional oil") have been found and because of the need to diversify from 
politically unstable regions, oil companies now look at more challenging environments such as deep sea for oil exploitation (The Boston Globe, 2005) or so-called nonconventional oil resources such as oil sands (mainly in Canada), extra heavy oil (Venezuela) and oil shales (USA) (Greene et al., 2006). Other options for mitigating the risk of oil depletion are coal liquefaction (already undertaken at a large scale in South Africa) and gas-to-liquids processes (Hirsch, 2005). The extraction from nonconventional resources is extremely energy-intensive and results in large amounts of greenhouse gas emissions. This may constrain the full exploitation of those resources (Knapp, 2004; Strahan, 2007; Vidal, 2005).

\section{$\underline{\text { Tourism and oil }}$}

Forecasts by the IEA (2006) indicate that $20 \%$ of the growth in energy demand between now and 2030 (over one-half) is due to increasing demand for transportation worldwide. Petroleum or crude oil is is the basis for products such as fuel oil (including diesel), and petrol (also called gasoline) and kerosene, which is used in jet fuel for aircraft. In the distillation of crude oil, the largest part ( $84 \%$ or 37 of 42 gallons in a barrel) is processed as fuels, with $16 \%$ being converted into other materials such as plastic (Energy Information Administration, 2006). Fuels are essential for all conventional tourism transport.

Transport already consumes over $50 \%$ of total oil per annum globally (this proportion is higher in developed countries). Jet fuel consumption for aviation alone is about 2 billion barrels or 240 million tonnes per annum (Busby, 2002). In the planning of airport runway extensions, the UK is assuming that passenger volumes will double by 2015 and triple by 2030. Similarly, Airbus is expecting an annual growth rate of $4.5 \%$ starting in 
2000. Busby (2002) calculated that if peak oil was reached in 2007 , it would not be possible to meet the jet fuel demand of the forecast air traffic volumes. He concluded that over the 25 years leading up to 2030 , only around $60 \%$ of the passenger and $45 \%$ of the freight markets' requirements could be met. There seems to be little evidence that the tourism sector is aware of the issues around peak oil and its implications.

Tourist destination managers should be concerned about oil for several reasons. First, oil scarcity and lack of alternatives (e.g. for aviation) will lead to higher prices for travel and as a result lower demand. Studies on price elasticity for air travel show, however, that it is necessary to distinguish between air travel segments, such as business and leisure, long-haul and short-haul, and national and international travel (Gillen et al., 2004). Long-haul and business travel are generally less elastic than other travel. Oil prices will not only affect tourists' decision making in relation to where to go, but also how (extensively) they travel once at the destination.

Second, an extreme scenario of oil depletion as evidenced in the models for peak oil means that oil would - at some stage - only be available for life-supporting industries and tourism travel will not be a priority in oil allocation. Market composition to a destination is likely to change dramatically up to the extreme of no international tourism, but an increase in domestic tourism and local recreational activities that involve minimum mobility. Finally, oil consumption is linked with a range of other risks independent on when oil production is peaking. Above all, the combustion of fossil fuel contributes to enhanced carbon dioxide concentrations in the atmosphere, contributing to climate change, which is now accepted as a major social and economic challenge that requires urgently moving away from fossil fuels (Stern, 2006). Oil consumption also leads to other environmental impacts, such as local air pollution, and 
poses security concerns for countries that depend on imported oil from politically unstable areas. Media coverage of environmentally conscious travellers abandoning air travel has increased substantially in recent months (e.g. Rosenberg, 2007).

Given the above models of reduced oil production in the future, it is therefore timely and prudent for tourist destinations to consider their current oil requirements for tourism and plan for a future where oil is unavailable, very expensive or intolerable because of climate change constraints. A key element in this is to reduce tourism's requirements for fossil fuel, both for travel to and within the destination. There are many ways of contributing to such a goal at the destination level, for example through reducing the need for energy inputs (e.g. passive building), improving energy efficiency in the accommodation and transport sectors, and encouraging the use of renewable energy sources (e.g. Bode et al., 2003; Curtis, 2002; Warnken et al., 2004). Another way is to identify the energy requirements of different markets and then to target those markets that provide the greatest overall benefit compared to their oil inputs. This latter approach also allows taking into account the fuel requirements for travel between the country of origin and the destination. To assist decision-makers in this task, this paper explores a range of indicators for assessing and monitoring the oil consumption of different markets. Ten indicators will be tested for the case of New Zealand. The focus of this paper is on tourism transport rather than other tourism sub-sectors (e.g. accommodation) for which oil is less critical, as other energy sources are (more readily) available (e.g. electricity).

\section{Deriving indicators for tourism's oil intensity}

In the following, 10 indicators for oil intensity of different markets are derived for 
measuring oil consumption at different scales and with various end-uses in mind.

Oil requirements can be classified into destination-based and transit-related, that is travel between the origin and destination (OD) (Figure 2). Travel between the tourists' place of origin and the destination is often of an international nature ${ }^{1}$, especially when it involves long-distance (air) travel. Initially, a destination (and its tourism industry) may wish to analyse oil requirements within its (geographic and/or administrative) borders, as this is most relevant for short-term planning and management (e.g. requirements to import oil), and the successful delivery of the tourism product. However, in an oilconstrained world the OD component of tourist travel will become increasingly expensive and therefore tourists may find it difficult to travel to certain destinations. Therefore, medium to long-term assessments should also include the oil requirements of OD travel.

Within destination-based and OD-related transport, two scales of measurement can be distinguished: first, aggregate oil requirements by market, and second, oil use by individual tourists. Indicators are then derived at those two levels: seven indicators (I VII) deal with oil use at the destination and three indicators (VIII - X) measure oil intensity related to OD travel. All the indicators are measured in megajoules, except eco-efficiency, which is measured as dollars per megajoules.

FIGURE 2 ABOUT HERE

\section{$\underline{\text { Destination-based indicators }}$}

\footnotetext{
${ }^{1}$ For some large countries, long-distance travel does not necessarily involve crossing borders and would therefore be classified as domestic travel.
} 
I. Total domestic oil use by market: Total oil use is derived by adding a market's total travel distance for each transport type within the destination, multiplying these distances by the respective energy intensities and summing oil use for all transport types. This provides information on which markets would be the prime target of communication campaigns or policies designed to minimise oil consumption in the event of oil shortages. Thus, oil saving strategies could be directed at markets where most impact is expected.

II. Oil use by domestic air transport: Oil use for domestic air transport at the destination is obtained by summing domestic air travel distances for each market and multiplying the result with the average energy intensity for air travel. The propensity to fly internally has ramifications on oil demand (and also on greenhouse gas emissions), as air travel tends to be more energy-intensive than road travel.

III. Oil use by domestic road transport: Oil use by domestic road transport is obtained by summing up road travel distance at the destination for each market and multiplying it with the average energy intensity for road travel. Knowing the amount of energy used for road transport is useful to assess potentials for new technology developments (e.g. renewable energy sources) and substitution options (e.g. rail transport). There is also opportunity for behavioural change, although earlier research has demonstrated that changing road transport behaviour of self-drive tourists is very challenging (Becken \& Wilson, 2007).

IV: Ratio of domestic air transport oil use to total domestic oil use: The ratio of oil used for domestic air transport compared with total oil requirements at the destination shows the relative importance of internal air travel for each market. This informs assessments 
for energy efficiency potentials for different markets. The focus for markets that are characterised by high air/total oil use ratios would be on supporting a modal shift from domestic air to land transport, whereas strategies for markets with a low air/total oil use ratio would focus directly on substituting oil-intensive road transport by more efficient or non-fossil fuel based alternatives.

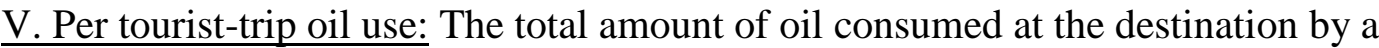
market says little about the travel behaviour of individual tourists, and for this reason it is useful to measure 'per tourist-trip' oil use. This provides insights into the relative energy intensity of different travel styles that might be typical of each market.

Information on domestic oil use at the level of an individual tourist can be used to inform marketing campaigns, or support fuel-saving initiatives tailored to each market. Oil use per tourist trip is derived by dividing the total domestic oil use for each market by the number of arrivals (volumetric average).

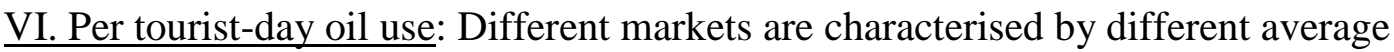
length of stays and additional information on oil-intensity can be gained by normalising domestic oil use by the number of days spent at the destination. This indicator is derived by dividing average oil use per trip by average length of stay for each market.

VII. Eco-efficiency: tourist expenditure versus domestic oil use: Oil requirements at the destination can usefully be juxtaposed with tourist expenditure (as an indicator of economic impact) to indicate costs and benefits generated by a market. This measure of eco-efficiency has been used to compare the 'desirability' of different markets to a destination (Gössling et al., 2005). Eco-efficiency is derived by calculating the ratio between total expenditure (at the destination, excluding costs for transit travel) per 
person and total domestic energy use per person for each market.

\section{Origin-destination indicators}

New Zealand is a long distance from most of its source markets, except from Australia. Such a remote location leads to a high dependency on oil for bringing tourists to New Zealand and back to their home country. The OD indicators build on an earlier study on energy use associated with different markets travelling to New Zealand by international air (Becken, 2002). The travel distances between tourists' home country and New Zealand were taken from that earlier study.

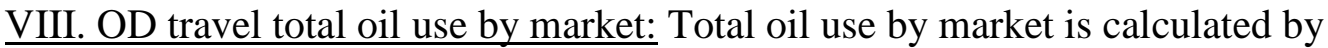
multiplying average individual oil use for OD travel (see indicator IX) by the number of arrivals. This gives an indication of a market's overall dependency on oil for travelling to and from the destination.

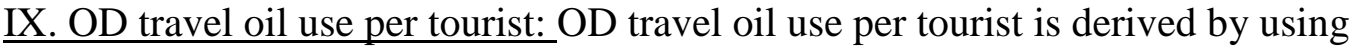
proxies for average travel distance between a country of origin and the destination, and by multiplying these with the average energy intensity for international air travel. The amount of oil used for a particular journey gives an indication of costs for this journey. Destination specific research is required to assess price elasticities for different markets, as earlier research indicates a wide spread of price sensitivity depending on various factors, for example purpose of travel (Brons et al., 2002).

$\underline{X}$. Ratio of OD travel oil use to overall oil use: The overall oil use of a tourist trip is the sum of oil use at the destination (Indicator V) and oil use for OD travel (Indicator IX). 
The proportion of oil use for transit travel of this overall oil use tells to what degree a tourists' oil consumption is dominated by the OD travel component. From a global perspective is important to know which component - the destination-based or OD related energy use- is the driver of total oil requirements, as this determines the levers for reduction strategies.

\section{Data used for the case study of New Zealand}

The data used for the following analysis stem from the 2005 International Visitor Survey (IVS), which is undertaken on an ongoing basis in New Zealand as part of the Ministry of Tourism's Core Data Set. The IVS is undertaken in the form of an exit survey at New Zealand's main international airports in Auckland, Christchurch and Wellington. Collectively these airports are the exit point for $98 \%$ of all international visitors. The sample comprises visitors over 15 years of age who are surveyed face-toface by multilingual interviewers. Approximately 5,500 visitors are now interviewed each year.

Among other things the IVS collects information on transport modes, accommodation used and attractions/activities visited by tourists. It is also possible to create sequenced travel itineraries from the survey responses (Forer, 2005) by analysing travel sectors. A travel sector (distinguished into road, other and air) is defined as any travel between overnight stops or stops that are longer than one hour. For the purpose of this analysis the sequence of travel sectors is not relevant, as only total travel distance is analysed. To this end, the existing database was enhanced by travel distances for road and other ${ }^{2}$ transport (based on information provided by the Automobile Association), and air travel

\footnotetext{
${ }^{2}$ Other included travel by train, bike, and water transport.
} 
(shortest distance). Consequently, travel sectors could be added up to calculate travel distances for different markets.

Travel distance was converted into energy use using an estimated energy intensity of 2.5 MJ per passenger-kilometre $(\mathrm{MJ} / \mathrm{pkm})$ for domestic air travel and $1.75 \mathrm{MJ} / \mathrm{pkm}$ for international air travel (Becken, 2002). Road transport within New Zealand was assumed to have an average energy intensity of $0.9 \mathrm{MJ} / \mathrm{pkm}$ (Becken \& Cavanagh, 2003). These estimates take into account that the fuels typically used (i.e. petrol, diesel or aviation fuel) have different energy contents, and that transport modes (e.g. cars and campervans) differ in their energy intensity. Other transport was assumed to be associated with an average energy intensity of $1.5 \mathrm{MJ} / \mathrm{pkm}$, taking into account that water transport is comparatively energy intensive, as is train travel in the context of New Zealand's hilly terrain.

For the comparison of different markets, the Top10 markets to New Zealand were selected based on their 2005 arrivals. A country-of-origin segmentation was undertaken, as this typically reflects a destination's approach in terms of marketing and ability to approach different markets.

\section{Results for New Zealand}

The travel activity, measured as travel sectors, differs substantially for the Top 10 markets (Table 1). Tourists from Germany and the United Kingdom travel most sectors in New Zealand, whereas those from China travel least. The number of travel sectors is related to length of stay as those tourists staying longer tend to travel more; although 
there are exceptions, for example visitors from Singapore travel 7.1 sectors on average during a stay of 16 days, which is more than the 5.1 sectors traveled by Chinese during a stay of 24 days on average.

\section{TABLE 1 ABOUT HERE}

The markets also differ in the average distance travelled per sector. For road transport, Australian tourists travel only $158 \mathrm{~km}$ per sector, compared with $214 \mathrm{~km}$ travelled by American tourists. This is despite the fact that Australians spend less time in New Zealand than Americans, when one could have expected that sector travel distances would be greater for shorter staying markets. It is possible that the proximity of Australia and the possibility of repeat visitation leads to "slower travel" behaviour. Tourists from South Korea and China are also characterised by large travel distances per sector. Tourists from South Korea and Japan travel the largest distance by air, whereas tourists from Australia and the United Kingdom tend to travel shorter distances by air. These differences in transport behaviour are evident in the oil intensity indicators discussed below.

\subsection{Destination-based fuel requirements}

\section{Fuel use by aggregated market}

The following four indicators (I to IV) measure the oil intensity of the Top 10 markets in an aggregated form. First of all, total domestic energy use per market has been derived by adding energy use for internal air travel, road and other transport. More than half of total energy use by tourist transport in New Zealand (2.2 PJ out of $\left.4.2 \mathrm{PJ}^{3}\right)$ is due

\footnotetext{
${ }^{3}$ One petajoule is 1 billion megajoules.
} 
to the travel by three markets, namely Australia, the United Kingdom and the USA (Figure 3, see also Table 2 below). Australia contributes less to domestic oil requirements (22\%) than their share of arrivals (37\%), whereas Japan contributes more (10\% as opposed to $7 \%$ ). Markets that are not part of the Top 10 countries of arrival contribute almost one quarter ( $0.9 \mathrm{PJ})$ to oil consumption, which is roughly equivalent to their market share. Total oil consumption in New Zealand amounted to $262.4 \mathrm{PJ}$ in 2005 (Ministry of Economic Development, 2006); which means that destination-based transport by international tourists contributed about $1.6 \%$ to national oil use. This contribution is increasing according to the growth in international arrivals.

\section{FIGURE 3 ABOUT HERE}

The amount of oil consumed for domestic air and road travel are important indicators for the development of energy reduction strategies, including the assessment of infrastructure needs and technological potential at the destination. Japan, the UK and Australia are the largest oil consumer for air travel within New Zealand (Table 2). Germany stands out as a market that despite comparatively low overall requirements consumes considerable amounts of oil for road transport. Table 2 also shows that the German market has the lowest ratio of air energy use to total energy use; only $16 \%$ of total energy use is for domestic air travel. The United Kingdom, Canada and Germany are also characterised by low domestic air energy use ratios. The most domestic air travel dependant market is Japan with $60 \%$ of its energy use for the less energy efficient air travel mode. China, Taiwan and South Korea are also characterised by substantial domestic air travel energy requirements.

\section{TABLE 2 ABOUT HERE}




\section{Per tourist oil use (indicators V to VII)}

Information on the total domestic oil requirements of a market does not allow any conclusion about the oil-intensity of individual tourists from this market. Australian tourists, for example, have the lowest energy requirements per trip within New Zealand at about 1,270 MJ per tourist-trip (Table 3). In contrast, German tourists consume on average 3,930 MJ per tourist-trip for their transport in New Zealand. This is a consequence of a long stay and large travel distances. Japanese tourists are also oilintensive (3,077 MJ per tourist-trip and $162 \mathrm{MJ}$ per tourist-day) as a result of their propensity to travel by air internally, whereas Chinese tourists consume below average, both per tourist-trip (1,325 MJ) and per tourist-day (55 MJ/day).

\section{TABLE 3 ABOUT HERE}

The eco-efficiency of tourism has been analysed for various tourist destinations (e.g. Gössling et al., 2005; Peeters \& Schouten, 2005). Generally, this indicator compares the dollars spent by a market or tourist with the resources required to provide the service or good; in this case oil. The highest eco-efficiency of travel in New Zealand is associated with tourists from China (2.95 \$/MJ), Australia (2.22 \$/MJ) and Singapore (\$1.95 \$/MJ) (Table 3, indicator VII). These tourists spent comparatively large amounts of money compared with their oil consumption within New Zealand. The least eco-efficient markets are Canada (0.97 \$/MJ) and Germany (1.0 \$/MJ).

\subsection{Origin-Destination-related oil use}

The total oil requirements for travel to and from New Zealand by the Top 10 markets 
amount to $57 \mathrm{PJ}$, which is 14 times more than oil used for travel within New Zealand. If international air travel oil requirements were added to New Zealand's total oil consumption (262 PJ, see above), this would be equivalent to an increase in oil demand by $22 \%$.

At the aggregate level, the most oil-intensive market is the United Kingdom (mainly driven by distance), followed by Australia (driven by market size) and the USA (a combination of distance and market size). Japan, Korea, China and Germany make similar contributions to the total oil use involved in international travel to and from New Zealand (Figure 4). These calculations do not take into account that a number of tourists are visiting more than one country (e.g. New Zealand in combination with Australia), which has implications on actual travel distance and also on possible allocation mechanisms between multiple countries involved.

\section{FIGURE 4 ABOUT HERE}

Oil use involved in the return journey to New Zealand can also be calculated per tourist (Indicator IX) and juxtaposed to oil requirements for the trip within New Zealand (Figure 5). Due to their remoteness from the destination, Germany and the United Kingdom also have high oil requirements per person to get to New Zealand (and back). China has the highest ratio of international air travel energy use to overall energy use with $97.4 \%$ (Indicator X). This ratio is lowest for Australian (90.1\%) and second lowest for Japanese tourists (91.9\%). In any event, with all proportions being over $90 \%$ the very high dependence of New Zealand on international air travel becomes evident.

FIGURE 5 ABOUT HERE 


\section{Discussion}

In this paper, 10 indicators of oil intensity were applied to compare the Top 10 tourist markets to New Zealand. Each indicator offers useful insights into a slightly different aspect of oil use in relation to different markets. For a tourist destination, all indicators are important and markets can be ranked based on each indicator.

The first four destination-based indicators shown in Table 4 highlight those markets that deserve most attention in terms of energy conservation campaigns within New Zealand, most notably Australia, the United Kingdom and the USA. All of these markets are characterised by large oil requirements, in total, for domestic air and road transport. Japan is also of particular interest as it has the highest ratio of energy use for domestic air travel compared with total energy use at the destination. A high ratio indicates a need for strategies to substitute oil-intensive air travel by road transport and put in place other high-speed transport links, for example between the New Zealand North and South Islands. In contrast, those countries that have a low ratio of domestic air transport oil use compared to total internal oil use (those at the top of Table 4) already provide some potential for energy-efficient road-based alternative transport systems. This kind of information is useful for Ministries of Transport and other agencies that plan for future transport systems.

\section{TABLE 4 ABOUT HERE}

The next three indicators provide information on the oil intensity of individual tourists from each market. Australia and China appear to be the most energy-efficient markets, 
whereas Germany, the USA and Japan appear to be very energy-intensive on a per tourist basis. A similar pattern applies to the indicator of eco-efficiency; that is the amount of money spent per unit of energy consumed in New Zealand. The case of China illustrates, however, that more detailed analysis might be useful when a market is heterogeneous or when substantial structural change can be expected in the near future. At present, the Chinese market comprises holiday visitors (41\%), 'visiting friends and relatives' tourists $(23 \%)$, business travellers $(22 \%)$ and educational visitors $(7 \%)$. Those segments differ significantly in their average length of stay, for example, education visitors stay for 148 nights, whereas holiday visitors only spend 7 nights on average. The travel behaviour statistics for Chinese tourists are therefore influenced by those $59 \%$ of typically longer staying market segments. It is possible that long staying Chinese visitors are characterised by little travel but high spending (e.g. student fees) and therefore a very high eco-efficiency, whereas Chinese holiday visitors travel long distances while spending less and therefore having a lower eco-efficiency. Further analysis is recommended to fully understand segments within each market.

The analysis using the different indicators described above offers useful insights into the potential levers for oil saving measures for each market. For example, the Japanese market with its high propensity to travel by domestic air clearly requires a strategy to make road transport more available and attractive to that market. This is a great opportunity to introduce new transport technologies and systems; for example the hybrid car could be specifically marketed to potential Japanese self-drive tourists. The German market, on the other hand, is characterised by large road travel distances and strategies would need to aim at shortening daily travel distances, perhaps by engaging German tourists in more activities. If these activities involve a commercial operation 
(i.e. generating expenditure) the eco-efficiency of this market could be improved as well. Each market warrants analysis along oil efficiency dimensions.

The assessment of a market in relation to its oil intensity depends on whether a destination or a global perspective is taken. The last three indicators in Table 4 put the oil use at the destination in context with oil required to get there and back home again. It can be seen that for New Zealand closer markets such as Australia and Asia are more favourable than long-distance markets from Europe and North America. The United Kingdom, which is currently considered to be a growth market for New Zealand, is at particular risk under oil scarcity. Similarly, Germany as a market might be affected when oil prices rise, but given the large in-country oil consumption the ratio of international air travel to overall oil use is smaller than for example for China or Canada, and substantial gains can be expected from destination-based energy saving measures. For the case of New Zealand, any further growth from distant markets should be considered with caution as this is likely to more than outweigh any oil saving initiatives at the destination. New Zealand may be an extreme example in its dependency on international air travel, but other studies have also shown that OD travel is an extremely important (if not dominant) component of total oil consumption of tourism (e.g. Gössling et al., 2002; Peeters et al., 2004).

A global perspective would also require consideration of greenhouse gas emissions as a result of tourist transport. Aviation in particular is a comparatively energy-intensive form of travel resulting in large amounts of carbon dioxide emissions, but also considerable quantities of non-carbon dioxide greenhouse gases. These include nitrous oxides, water vapour and ozone, and the cumulative effect of those emissions in the upper troposphere (about $10 \mathrm{~km}$ altitude) could be about 2.7 times that of carbon 
dioxide alone (Penner et al., 1999). Currently, aviation is excluded from international agreements on climate change, such as the Kyoto Protocol, but there is a great likelihood that instruments will be put in place in the near future to control the growing emissions from aviation. The weight that decision makers might give to the domestic oil indicators (I-VII) compared with the international ones (VIII-X) depends on the particular situation of the destination, for example how far it is from its source market and the degree of tourist mobility at the destination.

Overall, the lowest risk markets for New Zealand with respect to oil requirements (and climate change policies) are Australia, China, Singapore, Taiwan and South Korea, although a more detailed analysis would be required in terms of sub sectors. Traditionally, marketing strategies are largely aimed at increasing visitor arrivals and increasing visitor spending. More recently, other aspects such as seasonality and regional spread are also taken into account for developing tourism strategies and marketing campaigns. In the future, it could prove beneficial to incorporate risk factors, such as those related to oil. Such risk assessments - including price sensitivity analyses - could inform the allocation of scarce marketing dollars.

Eco-efficiency is a particularly important indicator as it allows comparison of input and output in terms of economic contribution. If oil becomes a scarce resource, a destination has to consider carefully which industries provide the greatest return per litre of oil invested. Tourism is often treated as a luxury good (discretionary spending) on which additional charges (e.g. taxes or climate change levies) can be imposed to either raise revenue or regulate growth. In a recent analysis on air travel levies, Müller and Hepburn (2006) suggested that aviation could be subject to a climate levy, whereas international shipping should be exempt due to its importance for exports from developing (and 
other) countries. However, this proposition seems to overlook that tourism is also an export sector and increasingly important in many countries, especially in the developing world. It also seems to overlook that the negative effects of tourists' oil consumption may be - at least partly - be counterbalanced by tourists becoming more environmentally aware as a result of their travels and contact with nature.

Destinations have a vested interest in maintaining or growing tourist arrivals, possibly even at the expense of other industries if oil scarcity only allows for selected sectors to grow. For this reason, it would be useful to compare the assessment of tourism' s oil intensity - as demonstrated in this paper - with the oil requirements of alternative sectors, for example agriculture or horticulture. An early attempt has been made by Patterson and McDonald (2004) to compare tourism's eco-efficiency with other sectors. In this study, it turned out that tourism is among the least eco-efficient sectors in the New Zealand economy. More detailed studies with more recent data would be desirable to follow this line of analysis.

\section{Conclusion}

This paper demonstrates that oil requirements for tourism are large, especially in relation to OD travel. The analysis also shows that there are substantial differences in oil use between the Top 10 markets to New Zealand. These differences result from different lengths of stay, travel itineraries and transport mode choices. Oil requirements by a market also depend on the distance between the country of origin and the destination, in this case New Zealand. The 10 indicators provide detailed information on the different aspects of oil use by each market. Eco-efficiency as the ratio between 
tourist expenditure and oil use at the destination is particularly useful to assess the overall benefit of a market. However, it is important to note that while eco-efficiency might improve over time, total oil requirements might still increase as a result of growing volumes. For this reason, eco-efficiency should be used in conjunction with an indicator that measures absolute oil use. The use of such indicators is currently being assessed by the New Zealand Ministry of Tourism as part of their Strategy Review.

Given the increasing certainty that oil resources will be depleted at some point and that a transition to non-fossil fuel energy sources is inevitable, it is surprising that there is very little debate about what this means for tourism. A transition to less oil-intensive tourism is inevitable. Timeframes depend on the viewpoint that is taken, but as Greene et al., 2006 point out it is not too soon to think about paths to non-carbon energy sources and economies. For tourism destinations this might mean to consider carefully which markets are viable in the long-term and whether tourism is competitive relative to other industries when measured on the basis of eco-efficiency. For destinations that rely totally on international air travel it might also be wise to consider (re)investing into domestic tourism, including the development of fossil-free transport systems. 


\section{References}

Becken, S. \& Cavanagh, J. (2003). Energy efficiency trend analysis of the tourism sector. Research Contract Report: LC02/03/293. Prepared for the Energy Efficiency and Conservation Authority.

Becken, S. \& Wilson, J. (2007). Trip planning and decision making of rental vehicle tourists - a quasi-experiment. Journal of Travel and Tourism Marketing 20 (3/4). 47-63.

Becken, S. (2002). Analysing International Tourist Flows to Estimate Energy use Associated with Air Travel. Journal of Sustainable Tourism, 10 (2), 114-131.

Bentley, R. W. (2002). Global oil \& gas depletion: an overview. Viewpoint. Energy Policy, 30, 189-205.

Bode, S., Hapke, J. \& Zisler, S. (2003). Need and options for a regenerative energy supply in holiday facilities. Tourism Management, 24, 257-266.

Brons, M., Pels, E., Nijkamp, P. \& Rietveld, P. (2002). Price elasticities of demand for air travel: A meta-analysis. Journal of Air Transport Management, 8, 165-175.

Busby, J. (2002). The Busby Report: A national plan for survival in the $21^{\text {st }}$ Century. http://www.after-oil.co.uk/

Campbell, C. J. \& Laherrère, J. H. (1998). The end of cheap oil. Scientific American, March, 60-65.

Curtis, I.A. (2002). Environmentally Sustainable Tourism: A Case for Carbon Trading 
at Northern Queensland Hotels and Resorts, Australian Journal of Environmental Management, 9, 27-36.

Dorian, J. P.; Franssen, H. T. \& Simbecke, D. R. (2006). Global challenges in energy. Energy Policy, 34, 1984-1991.

Duncan, R. C. \& Youngquist, W. (1999). Encircling the Peak of World Oil Production. Natural Resources Research, 8 (3), 219-232.

Energy Information Administration (2006). Energy Kid's Page. Available at (12/12/06) http://www.eia.doe.gov/kids/energyfacts/sources/non-renewable/oil.html

Forer, P. (2005). Tourist Flows and Dynamic Geographies: Applying GI Science to Understanding Tourism Processes. In Simmons, D. \& Fairweather, J. (eds). Pathways to Sustainable Tourism.

Gillen, D. W., Morrison, W. G. \& Stewart, C. (2004). Air Travel Demand Elasticities: Concepts, Issues and Measurement. Final report. Department of Finance Canada. Available at (20/11/06) http://www.fin.gc.ca/consultresp/Airtravel/airtravStdy_e.html

Gössling, S., Borgström Hansson, C., Hörstmeier, O. \& Saggel, S. (2002). Ecological footprint analysis as a tool to assess tourism sustainability. Ecological Economics, $43(2-3), 199-211$.

Gössling, S., Peeters, P., Ceron, J.P., Dubois, G., Patterson, T. \& Richardson, R. (2005). The eco-efficiency of tourism. Ecological Economics, 54 (4), 417-434.

Greene, D. L., Hopson, J. L. \& Li, J. (2006). Have we run out of oil, yet? Oil peaking 
analysis from an optimist's perspective. Energy Policy, 34, 515-531.

Hirsch, R. L. (2005). The inevitable peaking of world oil production. Bulletin of the Atlantic Council of the United States. Vol. XVI, No. 5, 1-9.

Hutter, F. (2006). TrendLines Peak Oil Depletion Scenarios 2006. Available at (15/11/06) http://www.trendlines.ca/economic.htm

International Energy Agency (2005). Resources to Reserves- Oil and Gas Technologies for the Energy Markets of the Future. Available at (20/06/07) http://www.iea.org/Textbase/publications/free_new_Desc.asp?PUBS_ID=1568

International Energy Agency (2006). World Energy Outlook. OECD. Paris.

Knapp, D. (2004). Update on the competitiveness of non-conventional oil. Second Joint IEA/OPEC Workshop on Oil Investment Prospects on Oil Investment Prospects, Paris, April 28, 2004. Available at (28/06/07) http://www.iea.org/Textbase/work/2004/opec/knapp.pdf

Ministry of Economic Development (2006). Energy \& Resources. Available at (29/10/06) http://www.med.govt.nz/templates/StandardSummary__33.aspx

Müller, B. \& Hepburn, C. (2006). IATAL - an outline proposal for an International Air travel Adaptation Levy. Oxford Institute for Energy Studies, EV36. October 2006.

Patterson, M.G. \& McDonald, G. (2004). How green and clean is New Zealand Tourism? Lifecycle and Future Environmental Impacts. Lincoln: Landcare Research.

Peeters, P., van Egmond, T. \& Visser, N. (2004). European Tourism, Transport and Environment. Final Version. Breda: NHTV CSTT. 
Peeters, P. \& Schouten, F. (2006). Reducing the Ecological Footprint of Inbound Tourism and Transport to Amsterdam. In S. Becken \& B. Lane (Eds). Tourism and Transport - the Sustainability Dilemma. Special Issue: Journal of Sustainable Tourism, 14 (20), 157-171.

Peeters, P., Gössling, S. \& Becken, S. (2006). Innovation towards tourism sustainability: climate change and aviation. Special Issue International Journal of Innovation and Sustainable Development, 1 (3), 184 - 200.

Penner, J., Lister, D., Griggs, D., Dokken, D. \& McFarland, M. (Eds.) (1999). Aviation and the Global Atmosphere. A Special Report of IPCC Working Groups I and III. Published for the Intergovernmental Panel on Climate Change. Cambridge: University Press.

Rosenberg, S. (2007). Germans stay home for eco-holiday. BBC News, 8 May. Available at (12/05/07) www.newsvote.bbc.co.uk

Stern, N. (2006). Stern Review on the Economics of Climate Change. HM Treasury. Available at (14/11/06) http://www.hmtreasury.gov.uk/independent_reviews/stern_review_economics_climate_change/st ernreview_index.cfm

Strahan, D. (2007). End of oil heralds climate pain. Viewpoint. BBC News (30/03/2007) http://newsvote.bbc.co.uk

The Boston Globe (December 11, 2005). Price rise and new deep-water technology opened up offshore drilling. http://www.boston.com/news/world/articles/2005/ 12/11/price_rise_and_new_deep_water_technology_opened_up_offshore_drilling 
Vidal, J. (2005). The end of oil is closer than you think. Guardian Limited (21 April, 2005). http://www.guardian.co.uk/life/feature/story

United Nations World Tourism Organisation (2001). Tourism 2020 Vision. Madrid, World Tourism Organization.

United Nations World Tourism Organisation (2006).The Impact of Rising Oil Prices on International Tourism. Special Report Number 26. Madrid.

United States Geological Survey (2002). World Petroleum Assessment 2000 Description and Results. US Geological Survey Digital Data Series. US Department of the Interior. Available at (13/05/07) http://pubs.usgs.gov/dds/dds-060/.

Warnken, J., Bradley, M. \& Guilding, C. (2004). Exploring methods and practicalities of conducting sector-wide energy consumption accounting in the tourist accommodation industry. Ecological Economics, 48, 125-141.

World Energy Council (2003). Drivers of the Energy Scene. London.

Yeoman, I., Lennon. J. J., Blake, A., Galt, M., Greenwood, C. \& McMahon-Beattie, U. (in press). Oil depletion: What does this mean for Scottish tourism? Tourism Management, in press. 
Table 1 Travel sectors (average) by domestic transport type and market (other transport is not shown in this table, as it is negligible compared to road and air travel)

\begin{tabular}{|l|c|l|l|l|l|c|}
\hline Origin & Tourists & $\begin{array}{l}\text { Length } \\
\text { of stay } \\
\text { (days) }\end{array}$ & $\begin{array}{l}\text { Travel } \\
\text { sectors } \\
\text { domestic } \\
\text { road }\end{array}$ & $\begin{array}{l}\text { Distance per } \\
\text { road sector } \\
(\mathbf{k m})\end{array}$ & $\begin{array}{l}\text { Travel } \\
\text { sectors } \\
\text { domestic } \\
\text { air }\end{array}$ & $\begin{array}{l}\text { Distance per } \\
\text { air sector } \\
\mathbf{( k m})\end{array}$ \\
\hline Australia & 797,885 & 12 & 5.9 & 158 & 0.3 & 427 \\
\hline UK & 279,952 & 29 & 11.7 & 188 & 0.6 & 536 \\
\hline USA & 192,720 & 19 & 8.1 & 214 & 0.6 & 633 \\
\hline Japan & 145,953 & 19 & 6.3 & 196 & 1.0 & 701 \\
\hline South Korea & 98,236 & 25 & 6.0 & 205 & 0.4 & 710 \\
\hline China & 83,609 & 24 & 4.7 & 171 & 0.3 & 608 \\
\hline Germany & 52,904 & 38 & 17.5 & 181 & 0.4 & 601 \\
\hline Canada & 40,452 & 26 & 10.9 & 195 & 0.4 & 617 \\
\hline Taiwan & 25,839 & 24 & 7.1 & 196 & 0.6 & 681 \\
\hline Singapore & 26,427 & 16 & 6.6 & 204 & 0.4 & 577 \\
\hline Other & 446,522 & 28 & 8.2 & 177 & 0.4 & 627 \\
\hline
\end{tabular}


Table 2 Oil use by market and domestic transport mode

\begin{tabular}{|l|l|l|l|c|}
\hline Origin & Indicator I & Indicator II & Indicator III & Indicator IV \\
& Energy total & Energy \\
(MJ) & $\begin{array}{l}\text { Energy } \\
\text { (MJ) }\end{array}$ & Ratio air to \\
& & & $\begin{array}{l}\text { domestic } \\
\text { road (MJ) }\end{array}$ & \\
\hline Australia & $911,019,644$ & $202,578,076$ & $657,537,989$ & $22.2 \%$ \\
\hline UK & $783,203,850$ & $208,861,415$ & $548,201,646$ & $26.7 \%$ \\
\hline USA & $508,853,236$ & $177,810,487$ & $294,916,127$ & $34.9 \%$ \\
\hline Japan & $416,454,482$ & $247,755,324$ & $160,609,560$ & $59.5 \%$ \\
\hline South Korea & $177,188,541$ & $69,381,459$ & $105,078,761$ & $39.2 \%$ \\
\hline China & $104,625,717$ & $42,801,342$ & $60,486,473$ & $40.9 \%$ \\
\hline Germany & $189,671,907$ & $29,475,570$ & $148,690,447$ & $15.5 \%$ \\
\hline Canada & $103,951,305$ & $24,153,038$ & $76,426,609$ & $23.2 \%$ \\
\hline Taiwan & $61,525,440$ & $28,201,848$ & $32,054,636$ & $45.8 \%$ \\
\hline Singapore & $47,484,434$ & $14,902,377$ & $32,067,144$ & $31.4 \%$ \\
\hline Other & $859,991,356$ & $263,294,431$ & $576,201,341$ & $30.6 \%$ \\
\hline All countries & $4,163,969,913$ & $1,309,215,368$ & $2,692,270,734$ & $31.4 \%$ \\
\hline & & & & \\
\hline & & & & \\
\hline
\end{tabular}


Table 3 Oil use per trip and per day (domestically) by market and eco-efficiency

\begin{tabular}{|c|c|c|c|c|}
\hline Market & $\begin{array}{l}\text { Indicator } V \\
\text { Per trip fuel use } \\
\text { (MJ) }\end{array}$ & $\begin{array}{l}\text { Indicator VI } \\
\text { Per day fuel } \\
\text { use (MJ) }\end{array}$ & $\begin{array}{l}\text { Indicator VII } \\
\text { Eco-efficiency } \\
\text { \$/MJ }\end{array}$ & $\begin{array}{l}\text { Spending } \\
\text { (NZ\$) }\end{array}$ \\
\hline Australia & 1,268 & 106 & 2.22 & $\overline{2,811}$ \\
\hline $\begin{array}{l}\text { United } \\
\text { Kingdom }\end{array}$ & 3,063 & 106 & 1.44 & 4,414 \\
\hline USA & 2,965 & 156 & 1.07 & 3,176 \\
\hline Japan & 3,077 & 162 & 1.16 & 3,562 \\
\hline South Korea & 1,959 & 78 & 1.49 & 2,920 \\
\hline China & 1,325 & 55 & 2.95 & 3,908 \\
\hline Germany & 3,932 & 103 & 1.00 & 3,922 \\
\hline Canada & 2,801 & 108 & 0.97 & 2,727 \\
\hline Taiwan & 2,109 & 88 & 1.72 & 3,630 \\
\hline Singapore & 2,246 & 140 & 1.95 & 4,370 \\
\hline $\begin{array}{l}\text { Other } \\
\text { countries }\end{array}$ & 2,083 & 74 & 2.19 & 4,570 \\
\hline
\end{tabular}


Table 4 Ranking of markets according to the 10 indicators of oil intensity

\begin{tabular}{|c|c|c|c|c|c|c|c|c|c|c|}
\hline \multirow[b]{2}{*}{ Ranking } & \multicolumn{4}{|c|}{ Related to total oil use in NZ } & \multicolumn{3}{|c|}{ Related to per tourist oil use in NZ } & \multicolumn{3}{|c|}{ International travel component (OD travel) } \\
\hline & $\begin{array}{l}\text { Oil total } \\
\text { (highest to } \\
\text { lowest) }\end{array}$ & $\begin{array}{l}\text { Oil air } \\
\text { (lowest to } \\
\text { highest) }\end{array}$ & $\begin{array}{l}\text { Oil road } \\
\text { (lowest to } \\
\text { highest) }\end{array}$ & $\begin{array}{l}\text { Ratio oil } \\
\text { air to oil } \\
\text { total } \\
\text { (lowest to } \\
\text { highest) }\end{array}$ & $\begin{array}{l}\text { Oil per } \\
\text { tourist trip } \\
\text { (lowest to } \\
\text { highest) }\end{array}$ & $\begin{array}{l}\text { Per tourist } \\
\text { day oil } \\
\text { (lowest to } \\
\text { highest) }\end{array}$ & $\begin{array}{l}\text { Eco- } \\
\text { efficiency } \\
\text { (\$/MJ in } \\
\mathrm{NZ} \text { ) } \\
\text { (highest to } \\
\text { lowest) }\end{array}$ & $\begin{array}{l}\text { Oil total OD } \\
\text { travel } \\
\text { (lowest to } \\
\text { highest) }\end{array}$ & \begin{tabular}{|l} 
Oil per \\
tourist OD \\
travel \\
(lowest to \\
highest)
\end{tabular} & $\begin{array}{l}\text { Ratio oil OD } \\
\text { travel to overall } \\
\text { oil (lowest to } \\
\text { highest) }\end{array}$ \\
\hline 1 & Singapore & Singapore & Singapore & Germany & Australia & China & China & Singapore & Australia & Australia \\
\hline 3 & Canada & Taiwan & China & Canada & South Korea & Taiwan & Singapore & Canada & Taiwan & USA \\
\hline 4 & China & Germany & South Korea & UK & Taiwan & Germany & Taiwan & Korea & Japan & Singapore \\
\hline 5 & $\begin{array}{l}\text { South } \\
\text { Korea }\end{array}$ & China & Canada & Singapore & Singapore & UK & $\begin{array}{l}\text { South } \\
\text { Korea }\end{array}$ & Germany & Korea & Taiwan \\
\hline 6 & Germany & $\begin{array}{l}\text { South } \\
\text { Korea }\end{array}$ & Germany & USA & Canada & Australia & UK & China & USA & Germany \\
\hline 10 & Australia & Japan & Australia & Japan & Germany & \begin{tabular}{|l|} 
Japan \\
\end{tabular} & Canada & UK & Germany & China \\
\hline
\end{tabular}




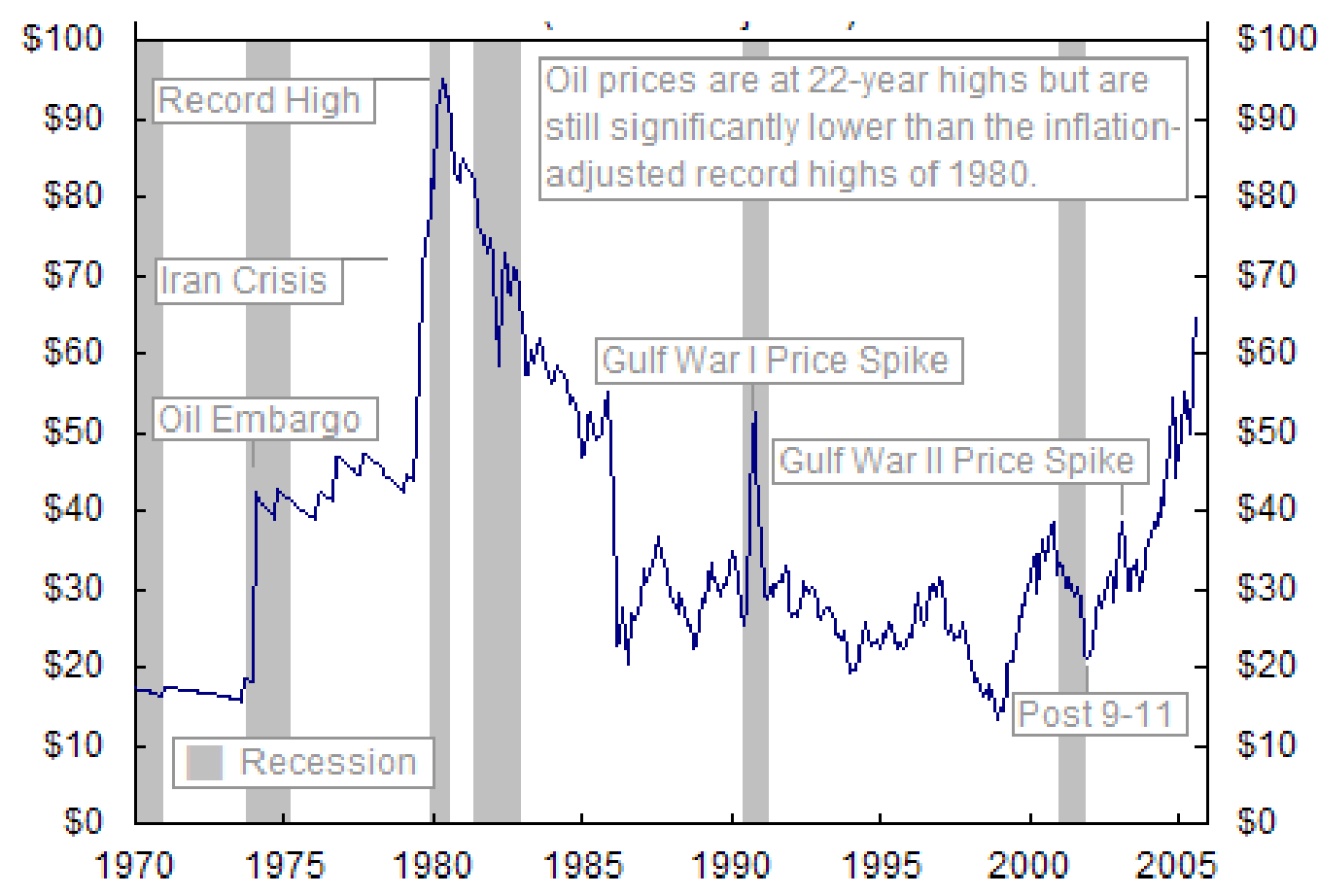

Figure 1 Historic oil prices and world events (inflation adjusted) (Source: Hutter, 2006). 


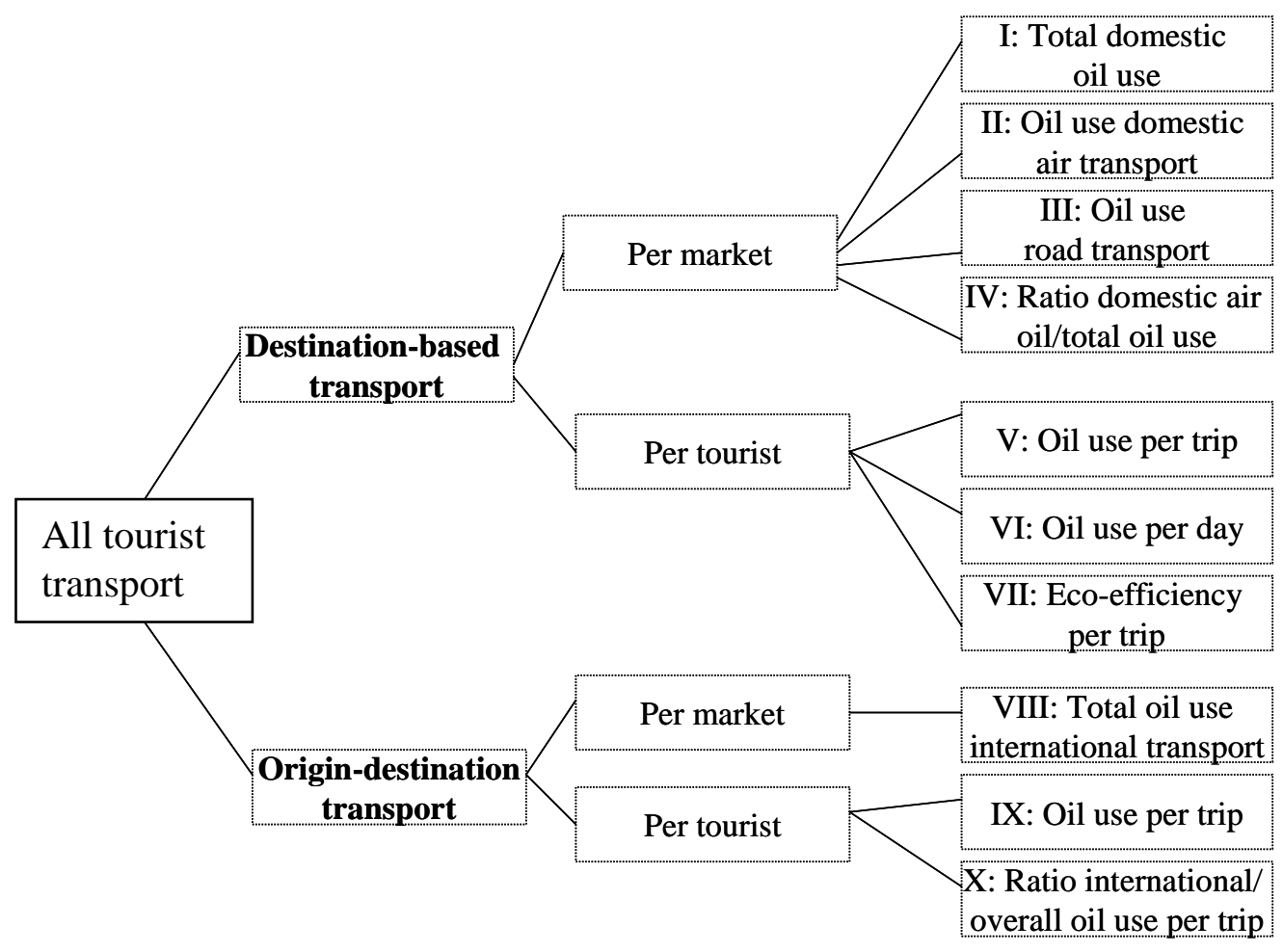

Figure 2 Categorisation of oil use and 10 indicators to assess a market's oil intensity. 

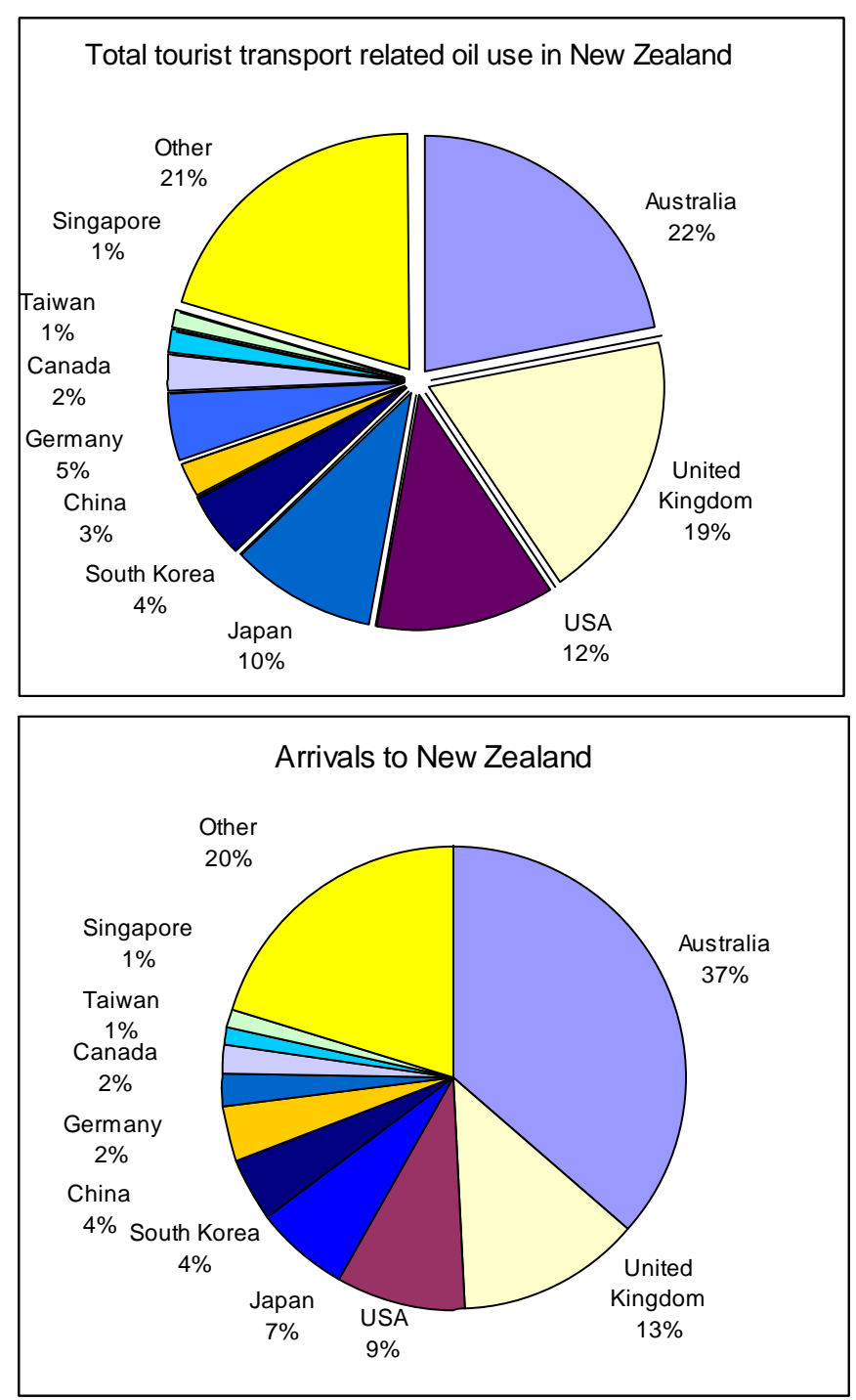

Figure 3 Total tourist transport related oil use in New Zealand by market in 2005 and tourist arrivals to New Zealand, by market, 2005. 


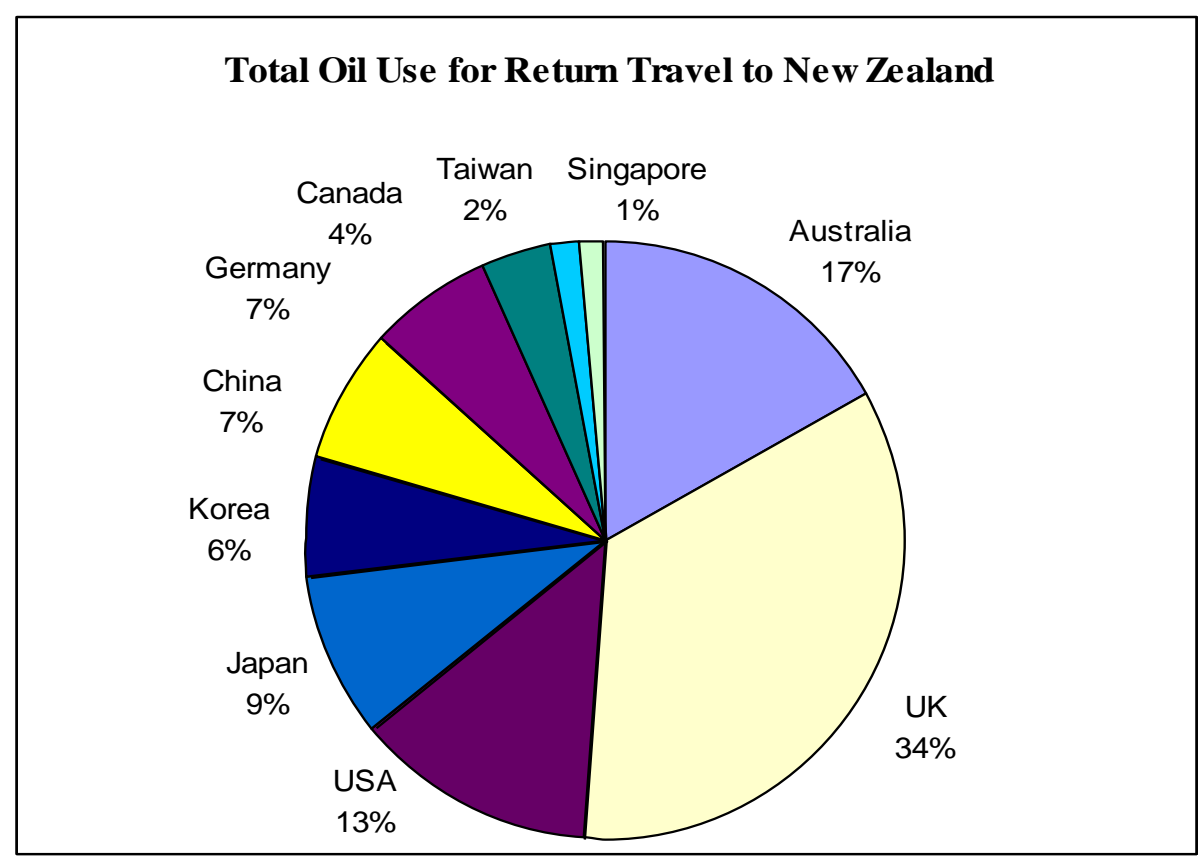

Figure 4 Total oil use by visitors for return travel to New Zealand by market (2005). 


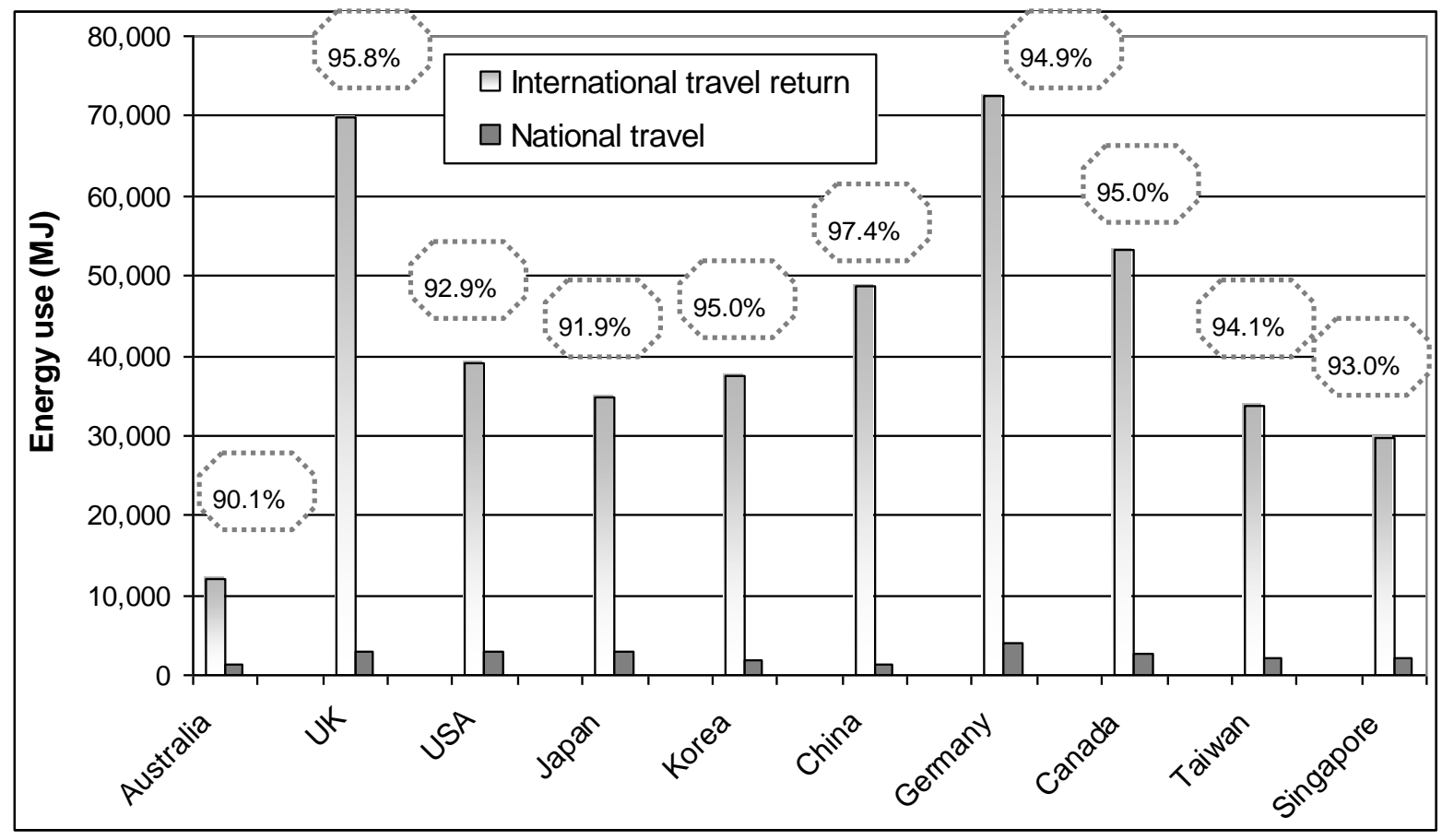

Figure 5 Comparison of per capita oil use for international travel to New Zealand and travel within New Zealand by market. The circles show the proportion of international air travel energy use to total energy use required for the whole trip (i.e. fuel use in New Zealand plus fuel use for international travel). 